\title{
PENGARUH PEREBUSAN, PENGGARAMAN DAN PENYIMPANAN TERHADAP PENURUNAN KANDUNGAN LISIN YANG TERDAPAT DALAM IKAN PINDANG
}

\author{
Jamal Basmal"), Bagus S.B. Utomo*) dan K.D.A. Taylor ${ }^{* *}$
}

\begin{abstract}
ABSTRAK
Pengamatan penurunan kandungan lisin dalam ikan pindang telah dilakukan terhadap produk yang disimpan dalam inkubator bersuhu $28^{\circ} \mathrm{C}$ dengan kelembaban relatif $100 \%$. Bahan pindang adalah ikan sardine beku (Sardina pilchardus juv) dari Portugal yang dilelehkan terlebih dahulu sebelum diolah. Ikan diolah dengan 4 macam perlakuan, yaitu direbus dalam 10\% larutan garam selama 22 menit (A), direbus dalam larutan garam jenuh selama 36 menit (B), dilakukan perebusan pendahuluan (pre-cooked) dengan penambahan 10\% garam kristal kemudian dikemas dan disterilisasi (C), dan dilakukan perebusan pendahuluan (pre-cooked) dengan penambahan $10 \%$ garam kristal kemudian dikemas, divakum dan disterilisasi (D). Kemudian produk A disimpan di inkubator dengan suhu $25^{\circ} \mathrm{C}$ dan kelembaban $100 \%$ selama: 4 hari, B: 8 hari, $\mathrm{C}$ dan D: 12 hari.
\end{abstract}

Hasil pengamatan menunjukkan bahwa kandungan lisin yang rusak akibat pengolahan pada perlakuan A adalah 3,36\%, B: 41,56\%, C: $53,17 \%$, dan D: $7,63 \%$ sedangkan setelah masa penyimpanan kerusakan kandungan lisin perlakuan A mencapai 48,50\%, B: 29,95\%, C: 26,50\% dan D: $27,99 \%$.

\section{ABSTRACT: Effects of boiling, salting and storage time on the content of available lysine in boiled salted fish. By: Jamal Basmal, Bagus S.B. Utomo and K.D.A. Taylor.}

Observation on available lysine degradation of salted boiled fish (ikan pindang) has been conducted. The raw materials used were individual quick frozen sardine (Sardina pilchardus juv) from Portugal which had been thawed before processing. The fish were processed in four different methods, i.e. boiled in 10\% salt solution for $22 \mathrm{~min}(\mathrm{~A})$, boiled in saturated salt solution for $36 \mathrm{~min}$ (B), pre-cooked with addition of $10 \%$ crystal salt, packed in non-vacuum plastic bags, and sterilised (C) and pre-cooked with addition of $10 \%$ crystal salt, packed in vacuum plastic bags and sterilised (D). The products were stored in an incubator at $28^{\circ} \mathrm{C}$ and $100 \%$ rh i.e. A for 4 days, $B$ for 8 days, while $C$ and $D$ for 12 days.

Results showed that after processing, the decrease of available lysine in A was $3.36 \%, B: 41.56 \%$, C: $53.17 \%$, and $D: 7.63 \%$, while after storage, the decrease of available lysine were $48.50 \%, 29.95 \%$, $26.50 \%$, and $27.99 \%$ for treatments $A, B, C$, and $D$ respectively.

KEYWORDS: Lysine; salted boiled fish; frozen sardine; storage time.

\section{PENDAHULUAN}

Beberapa komponen penyusun protein dalam bahan pangan mengalami perubahan selama pengolahan dan penyimpanan yang mengakibatkan penurunan kandungan protein. Perubahan ini akan mengurangi nilai gizi dan menyebabkan timbulnya bau busuk bahkan dapat menghasilkan senyawa-senyawa yang berbahaya bagi kesehatan. Finley (1985) melaporkan bahwa lisin (available lysine) sebagai salah satu komponen penyusun protein dapat rusak selama pengolahan karena senyawa tersebut peka terhadap perubahan $\mathrm{pH}$, oksigen, cahaya, panas, atau kombinasinya. Di samping itu, lisin dapat pula rusak selama perebusan dan sterilisasi, mudah teroksidasi, juga dapat rusak karena adanya aktivitas bakteri atau karena reaksi Maillard

\footnotetext{
*) Peneliti pada Balai Penelitian Perikanan Laut, Jakarta

**) Dosen pada University of Humberside, England
} 
yakni lisin akan bereaksi dengan gula-gula pereduksi membentuk lisinoalanin.

Ikan dan produk olahannya merupakan bahan makanan yang mempunyai kandungan asam amino lengkap termasuk 10 jenis asam amino esensial yang tidak dapat disintesis di dalam tubuh manusia. Di antara 10 macam asam amino esensial tersebut, lisin sangat mudah rusak baik oleh perlakuan fisik (suhu dan cahaya), adanya reaksi oksidasi lemak tak jenuh, reaksi Maillard, maupun oleh aktivitas bakteri. Selain itu, lisin akan bereaksi dengan asam amino lainnya melalui $\epsilon$-amino lisin dan membentuk lisinoalanin. Dalam menjaga sintasannya bakteri membutuhkan energi yang dapat diambil dari asam-asam amino (lisin) melalui suatu proses deaminase, sehingga lisin akan terdegradasi menjadi putresin dan $\mathrm{CO}_{2}$ (Obata et al., 1950; 1951; dan 1952 dalam Bramstedt dan Auerbach, 1961). Putresin yang terbentuk berpotensi mengeluarkan bau yang tidak diinginkan. Proses ini terutama akan terjadi selama penyimpanan produk yang disimpan dalam kondisi tidak bebas bakteri seperti dalam pengolahan ikan pindang dengan penerapan suhu tinggi tidak cukup untuk membunuh bakteri, ditambah pula kondisi penyimpanan yang tidak higienis akan mengakibatkan bakteri berkembang biak dengan cepat.

Bramstedt dan Auerbach (1961) menyatakan bahwa aktivitas bakteri dapat mengakibatkan terjadinya kerusakan asam-asam amino, khususnya asam glutamat, asam aspartat, lisin, histidin, dan arginin. Asam-asam amino tersebut bertindak sebagai precursor senyawa yang dapat menimbulkan bau dan rasa yang tidak sedap. Dengan latar belakang itulah maka penelitian ini dilakukan dengan tujuan untuk mencari metode yang dapat menekan penurunan kandungan lisin ikan pindang selama pengolahan dan penyimpanan.

\section{BAHAN DAN METODE}

\section{Bahan}

Penelitian ini menggunakan ikan sardin beku (Sardina pilchardus juv) dari Portugal. Hal ini dilakukan karena ikan tersebut mempunyai kesamaan dengan ikan lemuru dari Muncar, Jawa Timur, Indonesia dalam hal kandungan lemaknya. Ikan dilelehkan terlebih dahulu sebelum diolah di Laboratorium University of Humberside, England. Bobot ikan berkisar antara 57.94 g/ekor (rata-rata $71,3 \mathrm{~g}$ ) dengan panjang standar antara $5-17 \mathrm{~cm}$ (rata-rata $15,7 \mathrm{~cm}$ ).

Garam yang digunakan adalah garam yang telah memenuhi persyaratan sebagai bahan makanan dan pengemas adalah plastik polipropilen tahan panas.

\section{Metode}

Ikan sardin beku dilelehkan terlebih dahulu kemudian diolah dengan empat macam perlakuan, yaitu perebusan dalam $10 \%$ larutan garam selama 22 menit (A), perebusan dalam larutan garam jenuh selama 36 menit (B), perebusan pendahuluan selama 10 menit dengan penambahan $10 \%$ garam kristal kemudian dikemas dan disterilisasi pada suhu $121^{\circ} \mathrm{C}$ selama 72 menit (C) dan perebusan pendahuluan selama 10 menit dengan penambahan $10 \%$ garam kristal kemudian dikemas, divakum dan disterilisasi pada $121^{\circ} \mathrm{C}$ selama 72 menit (D). Semua produk disimpan dalam inkubator dengan suhu $28^{\circ} \mathrm{C}$ dan kelembaban $100 \%$ dengan lama penyimpanan berbeda menurut daya awetnya. A disimpan selama 4 hari, B selama 8 hari, C dan D selama 12 hari. Percobaan dilaksanakan dengan 3 kali ulangan.

Kandungan lisin dari A diukur setiap hari , B setiap 2 hari, sedangkan $C$ dan $D$ setiap 4 hari. Pengukuran kadar lisin menggunakan metode Carpenter (1960) dalam Peterson and Warthesen (1979). Penentuan kadar garam dengan menggunakan metode Anonymous (1972), jumlah bakteri total aerob (total viable count, TVC) ditentukan dengan metode Collins et al. (1989) terhadap perlakuan $\mathrm{A}, \mathrm{B}, \mathrm{C}$, dan $\mathrm{D}$, sedangkan untuk perlakuan $D$ ditambah dengan analisis bakteri anaerob. Pada perlakuan sterilisasi (C dan D) juga diukur suhu pusat ikan dengan menggunakan pencatat suhu (thermorecorder) untuk menentukan nilai $F_{0}$. Stumbo (1973) menyatakan bahwa nilai $F_{0}$ (suatu parameter untuk mengukur total waktu, dan suhu proses sterilisasi suatu bahan pangan agar produk terhindar dari bakteri patogen seperti Clostridium botulinum dan sporanya) sebaiknya di atas 3,6 agar produk aman dari bakteri patogen dan nilai $F_{o}$ (dihitung menggunakan rumus $F_{o}=\Sigma \mathrm{L}$.dt di mana L: $L$-value dari tabel pada suhu referensi dan dt: perubahan waktu), dapat ditentukan bila 
Basmal, J.; Utomo, B.S.B.; dan Taylor, K.D.A.

proses panas yang diberikan selama proses pengolahan lebih besar atau sama dengan $100^{\circ} \mathrm{C}$.

\section{HASIL DAN PEMBAHASAN}

\section{Tingkat Kesegaran Bahan Mentah}

Hasil analisis bahan mentah setelah dilakukan pelelehan (thawing) pada suhu kamar dapat dilihat pada Tabel 1 di mana ikan masih dalam keadaan segar dan ini terbukti dari nilai jumlah basa yang mudah menguap (TVB-N) sekitar 14,93 mgN\%. Berdasarkan parameter tingkat kesegaran ditemukan bahwa nilai TVB-N masih di bawah 30 mgN\% yang berarti ikan dapat dikategorikan segar. Connell (1980) dalam Wheaton and Lawson (1985) menyatakan bahwa ikan (tidak termasuk kelas ikan elasmobranchia) dikategorikan segar apabila nilai TVB-N nya di bawah $30 \mathrm{mgN} \%$. Sedangkan dari kandungan lemaknya ikan sardin yang dipergunakan pada penelitian ini dikategorikan dalam ikan berlemak tinggi (kandungan lemaknya 16,5\%) sehingga dalam pengolahannya memerlukan teknik tertentu agar tidak terjadi degradasi lemak selama pengolahan dan penyimpanan. Dampak nyata bila kandungan lemak telah teroksidasi adalah terbentuknya radikal bebas selama pengolahan dan penyimpanan yang kemudian akan bereaksi dengan protein seperti reaksi antara melanoidin (hasil oksidasi lemak) dengan protein atau dengan asam amino, sehingga kandungan nutrisi ikan akan berkurang.

\section{Pengaruh Perlakuan Panas dan Penggaraman}

Untuk menentukan perlakuan panas dan jumlah garam yang diperlukan guna menghambat pertumbuhan bakteri pada pengolahan ikan pindang, telah dilakukan penelitian awal yakni ikan direbus (tanpa tekanan) di dalam 3 macam larutan garam, yaitu 10\%, 15\%, dan $25 \%$. Hasilnya ternyata suhu tertinggi dicapai pada larutan garam $25 \%$ ialah sebesar $106^{\circ} \mathrm{C}$, sedangkan terendah tercapai pada larutan garam $10 \%$ yakni sebesar $102^{\circ} \mathrm{C}$. Dalam penelitian awal ini juga terlihat bahwa setelah ikan dimasukkan ke dalam larutan garam suhu turun kemudian meningkat kembali dan mencapai suhu maksimum setelah 12 menit perebusan. Pengujian jumlah bakteri (TVC) aerob yang dilakukan setelah produk direbus dalam masing-masing larutan garam selama 20 menit memberikan hasil kandungan bakteri aerob pada larutan garam $10 \%$ sebanyak $44 \mathrm{koloni} / \mathrm{g}$, tetapi pada larutan garam $25 \%$ tidak ditemukan koloni bakteri aerob. Untuk meyakinkan produk yang akan dibuat terbebas dari bakteri tahan panas maupun sporanya, telah dilakukan pula pene-litian menggunakan suhu sterilisasi pada suhu $118^{\circ} \mathrm{C}$, dengan total waktu proses 53 menit. Setelah dihitung nilai $\mathrm{F}_{\mathrm{o}}$ nya adalah 1,0803 yang berarti Clostridium botulinum dan sporanya masih bertahan hidup. Oleh sebab itu, untuk meningkatkan nilai $\mathrm{F}_{\mathrm{o}}$ pada penelitian selanjutnya dilakukan proses sterilisasi pada suhu $121^{\circ} \mathrm{C}$ selama 72 menit waktu proses.

Tabel 1. Komposisi proksimat dari ikan lemuru (Sardina pilchardus) setelah pelelehan.

Table 1. Proximate composition of sardine (Sardina pilchardus) after thawing.

\begin{tabular}{lrc}
\hline \multicolumn{1}{c}{ Parameter } & Nilai/Value \\
\hline Kadar protein kasar (Crude protein) & $(\%)$ & 13.60 \\
Kadar lemak (Fat content) & $(\%)$ & 16.50 \\
Kadar air (Moisture content) & $(\%)$ & 68.28 \\
Jumlah basa mudah menguap (TVB-N) & $\left(\mathrm{mgN}^{\prime}\right)$ & 14.93 \\
pH & & 6.29 \\
Kadar lisin (Lysine content) & $\left(\mathrm{mg}^{\mathrm{g}} \mathrm{db}\right)$ & 28.85 \\
Jumlah bakteri (TVC) & $\left(\mathrm{cfu} \mathrm{g}{ }^{-1}\right)$ & 214 \\
\hline
\end{tabular}


Hasil percobaan menunjukkan bahwa perebusan selama 72 menit untuk perlakuan $\mathrm{C}$ dan $\mathrm{D}$ memberikan nilai $\mathrm{F}_{0}=9,66$ (Lampiran 1), sementara nilai $F_{\circ}$ untuk $A$ dan $B$ adalah nol karena berdasarkan hasil pengamatan suhu pada pusat badan ikan menggunakan pencatat suhu selama perebusan tidak mencapai $100^{\circ} \mathrm{C}$ (Gambar 1). Dari hasil percobaan ini dapat dikatakan bahwa perlakuan $\mathrm{C}$ dan $\mathrm{D}$ aman dari C.botulinum dan bakteri lainnya, sedangkan perlakuan A dan $\mathrm{B}$ belum dapat dikatakan aman dari kedua jenis bakteri tersebut, karena produk tidak diperlakukan menggunakan suhu tinggi (sterilisasi).

\section{Perubahan Kandungan Lisin akibat Pengolahan}

Perbedaan kandungan lisin pada ikan pindang tidak hanya dipengaruhi oleh perbedaan perlakuan panas, tetapi juga oleh adanya cahaya, oksigen, radiasi dan sejumlah kecil ion logam seperti tembaga, mangan, dan besi yang merupakan katalis dalam mempercepat terbentuknya radikal bebas (ROO-). Ion-ion logam tersebut cukup tersedia dalam garam yang dipergunakan. Dampak adanya radikal bebas baik yang terbentuk oleh autooksidasi maupun yang dipercepat oleh ion-ion logam dan radikal bebas (ROO-) tersebut akan bereaksi dengan $\epsilon$-amino lisin, kemudian hasil reaksi tersebut dapat bereaksi dengan asam amino lainnya membentuk lisinoalanin. Hasil analisis lisin ikan sardin segar ditemukan sebanyak $28,85 \mathrm{mg} / \mathrm{g}$ dan setelah pengolahan, diperoleh lisin pada A sebesar 27,88 $\mathrm{mg} / \mathrm{g}$, pada B $16,86 \mathrm{mg} / \mathrm{g}$, pada C $13,51 \mathrm{mg} / \mathrm{g}$, dan pada D sebesar $26,65 \mathrm{mg} / \mathrm{g}$ bobot kering. Tooley dan Lawrie (1974) serta Yen dan Lii (1995) melaporkan bahwa asam-asam amino tertentu dalam bahan makanan dapat bereaksi dengan lisin selama pengolahan panas misalnya antara alanin dan lisin akan bereaksi menjadi lisinoalanin sehingga kandungan lisin akan berkurang. Pengurangan kandungan lisin terlihat jelas pada perlakuan C yakni dari $28,85 \mathrm{mg} / \mathrm{g}$ menjadi 13,51 $\mathrm{mg} / \mathrm{g}$ bobot kering. Hal ini disebabkan produk telah disteril kan pada suhu tinggi $\left(121^{\circ} \mathrm{C}\right)$ tanpa
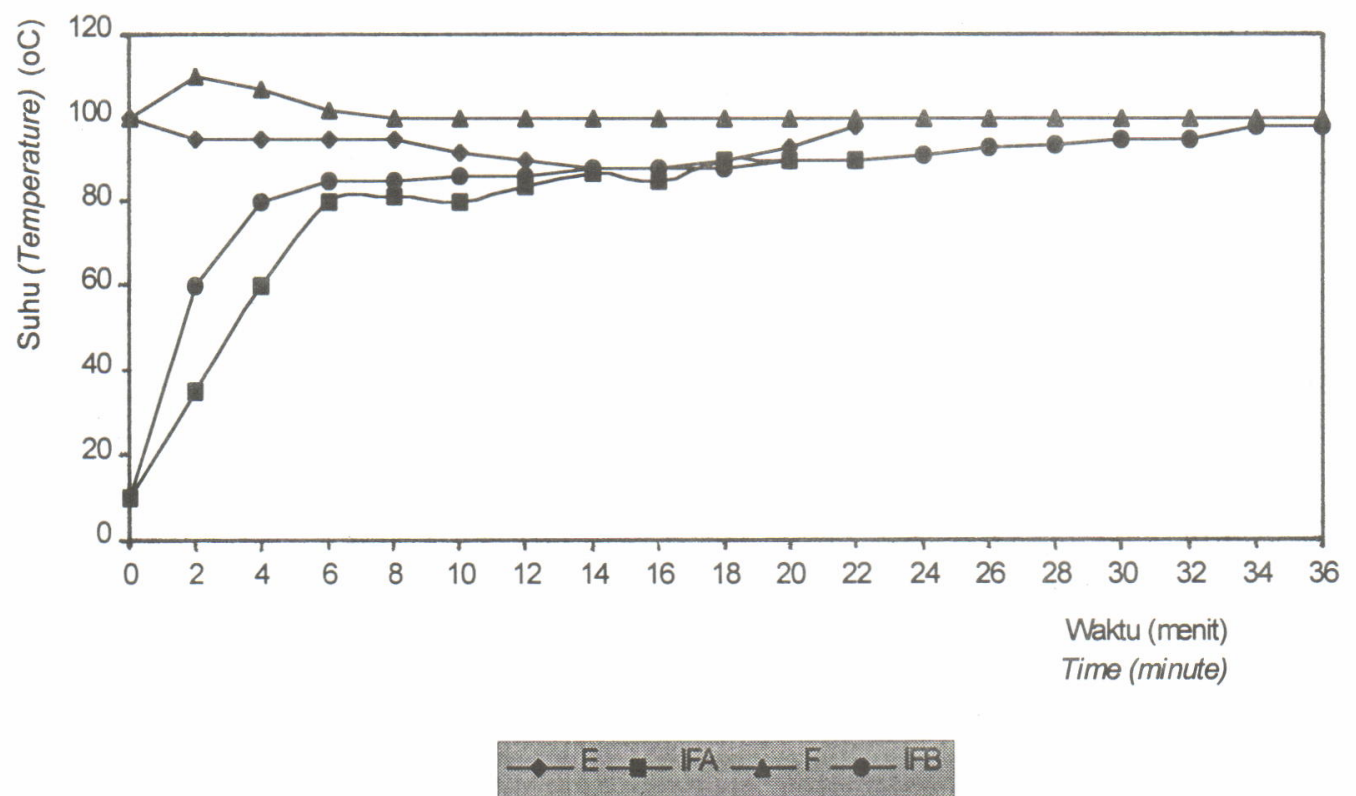

E: $\quad$ suhu medium perebusan perlakuan A (water medium temperature of $A$ treatment)

F: $\quad$ suhu medium perlakuan B (water medium temperature of $B$ treatment)

IFA: suhu pusat termal ikan perlakuan A selama perebusan (fish thermal center temperature in A treatment during boiling)

IFB: suhu pusat termal ikan perlakuan B selama perebusan (fish thermal centre temperature in $B$ treatment during boiling)

Gambar 1. Perubahan suhu medium dan suhu pusat badan ikan selama pengolahan.

Figure 1. Changes of medium and centre temperatures of fish body during processing. 
divakum, kemungkinan kombinasi antara suhu tinggi, oksigen, dan kadar garam yang terakumulasi di dalam daging ikan telah memicu tingginya kerusakan asam amino lisin. Hasil analisis kadar garam untuk perlakuan $\mathrm{C}$ adalah $8,40 \%$ bobot kering, dan $\mathrm{D}$ adalah $13,80 \%$ bobot kering. Meskipun kadar garam D lebih besar 5,4\% dari C namun kerusakan lisinnya lebih kecil. Ini diduga kuat bahwa kombinasi suhu tinggi, oksigen dan kadar garam telah mempercepat terjadinya kerusakan lisin selama pengolahan pada C.

Suhu pusat badan ikan selama pengolahan pada perlakuan $\mathrm{A}$ lebih rendah dari pada $\mathrm{B}$, sedangkan suhu B lebih rendah daripada $\mathrm{C}$ dan D. Pada Gambar 1 dapat dilihat fluktuasi suhu medium dan suhu pada pusat badan ikan perlakuan A dan B. Terbukti bahwa kombinasi larutan garam jenuh dengan suhu tinggi (walaupun di bawah suhu sterilisasi) dapat mengurangi kehilangan kadar lisin ikan pindang. Perlakuan A mempunyai kandungan lisin lebih tinggi daripada perlakuan B. Hal ini disebabkan perlakuan A direbus dalam larutan berkadar garam lebih rendah dan selama perebusan suhu pada pusat badan ikan A lebih kecil daripada suhu pada pusat badan ikan B, sehingga kecepatan penyerapan garam ke dalam daging ikan pada perlakuan B lebih besar daripada perlakuan A. Hasil analisis menunjukkan bahwa kadar garam perlakuan A adalah 9,78\%, dan B adalah 11,77\% (bobot kering). Konsekuensi penggunaan larutan garam jenuh adalah dapat meningkatkan ion-ion tembaga, mangan, dan besi. Ion-ion logam tersebut kemungkinan lebih banyak terserap ke dalam daging ikan jika dibandingkan dengan perlakuan A sehingga ion-ion tersebut dapat berfungsi sebagai katalis dalam reaksi ketengikan (oxidative rancidity) dan selanjutnya senyawasenyawa ketengikan (oxidative compound) yang sudah terbentuk akan dengan mudah bereaksi dengan asam amino seperti lisin yang terdapat dalam ikan pindang. Labuza, (1972) menyatakan bahwa reaksi antara ketengikan dengan asam amino disebabkan oleh adanya ion-ion logam (transition metal) dalam kristal garam yang dapat membentuk pirazin yang merupakan reaksi lanjutan antara asam amino tertentu dengan ketengikan. Gugus karbonil seperti aldehida, peroksida keton, ketohidroksi dan komponen epoksi (epoxy compound) dari oxidative products telah dihasilkan selama perlakuan panas tinggi. Semua komponen tersebut dapat bereaksi dengan asam-asam amino dari ikan seperti asam amino lisin. Proses yang terlihat nyata setelah produk diperlakukan dengan panas adalah terbentuknya warna kuning pada permukaan produk terutama pada perlakuan sterilisasi (C dan D) yang tidak lain akibat terjadinya reaksi Maillard atau disebabkan oleh reaksi antara gugus karbonil-amino dengan amin, asam-asam amino, dan aldehida atau keton. Reaksi tersebut akan berlanjut selama penyimpanan dan bereaksi dengan gugus $\epsilon$-amino dari lisin untuk menghasilkan pirazin atau piperidin. Pada Gambar 2 dapat dilihat proporsi kandungan lisin setelah pengolahan.

Kerugian lain yang dapat ditimbulkan oleh perlakuan panas yang tinggi di antaranya dapat menyebabkan terjadinya perubahan jaringan ikan seperti terbentuknya denaturasi protein, dan pemecahan trigliserida yang diikuti dengan reaksi sederhana lainnya seperti pembentukan gugus karbonil. Sedangkan keuntungan dari perlakuan panas tinggi di antaranya adalah menghentikan reaksi enzimatik dan membunuh jasad renik. Hasil percobaan ini menunjukkan bahwa pada produk perlakuan $\mathrm{C}$ dan $\mathrm{D}$ kandungan baik bakteri aerob maupun anaerob tidak terdeteksi, sementara pada perlakuan A ditemukan bakteri aerob sebanyak 38 koloni per gram dan B 20 koloni per gram. Penerapan perlakuan panas yang optimal diharapkan dapat mempertahankan bentuk fisik asli produk, memperpanjang daya simpan dan membunuh bakteri yang berbahaya seperti C.botulinum. Hasil pengamatan menunjukkan bahwa produk-produk $\mathrm{C}$ dan $\mathrm{D}$ aman dari bakteri anaerob karena setelah penyimpanan selama 12 hari terbukti kandungan bakteri anaerobnya tidak terdeteksi. Kerusakan lisin pada perlakuan $\mathrm{C}$ lebih besar dari pada perlakuan $\mathrm{D}$, hal ini kemungkinan disebabkan oleh pengaruh sistem pengepakan tanpa menggunakan vakum, sedangkan D dikemas dalam kondisi vakum.

\section{Perubahan Kandungan Lisin Selama Penyimpanan}

Hasil percobaan menunjukkan bahwa kandungan lisin cenderung berkurang selama penyimpanan. Penyusutan kandungan lisin pada perlakuan A sebesar $50.0 \%$ setelah disimpan selama 4 hari, B $30,55 \%$ setelah 8 hari, C $22,7 \%$ dan 


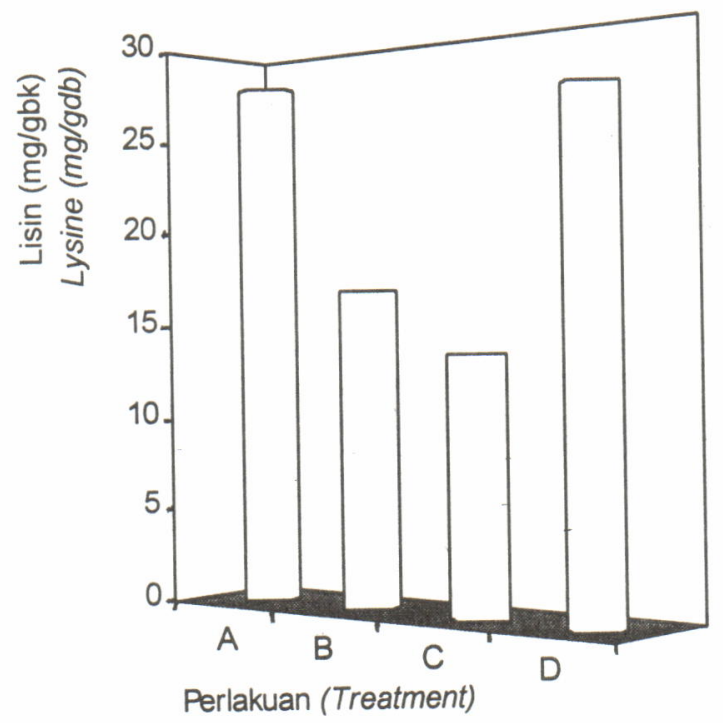

A: perebusan dalam 10\% larutan garam selama 22 menit (boiled in 10\% brine solution for $22 \mathrm{~min}$ )

$\mathrm{B}$ : perebusan dalam larutan garam jenuh selama 36 menit (boiled in saturated brine for $36 \mathrm{~min}$ )

C: penambahan $10 \%$ (b/b) garam kristal kemudian dikemas dan disterilkan pada suhu $121^{\circ} \mathrm{C}$ selama 72 menit waktu proses (pre-cooked with addition of $10 \%(\mathrm{w} / \mathrm{w})$ crystal salt, non vacuum packed, sterilized)

D: perebusan pendahuluan selama 10 menit dengan penambahan $10 \%$ (b/b) garam kristal kemudian dikemas vakum dan disterilkan pada suhu $121^{\circ} \mathrm{C}$ selama 72 menit waktu proses (pre-cooked with addition of $10 \%(\mathrm{w} / \mathrm{w})$ crystal salt, vacuum packed and then sterilised)

Gambar 2. Kadar lisin ikan pindang setelah pengolahan.

Figure 2. Lysine content of boiled salted fish after processing.

D sebesar $23,5 \%$ setelah 12 hari. Penurunan kandungan lisin pada semua perlakuan dapat dilihat pada Gambar 3. Kemungkinan besar penyusutan kandungan lisin pada A disebabkan oleh aktivitas bakteri dan faktor oksigen. Hasil pengujian bakteri aerob setelah penyimpanan adalah pada A sebanyak $1,7 \times 10^{5}$ koloni per gram, B 4,5 x $10^{5}$ koloni per gram, sementara C dan D tidak terdeteksi baik bakteri aerob maupun anaerob. Akibat aktivitas bakteri ini sejumlah besar asam-asam amino telah dimanfaatkan sebagai sumber energi melalui suatu proses deaminase, seperti lisin. Sebagai akibatnya lisin akan berubah menjadi kadaverin dan selanjutnya berubah menjadi putresin sehingga menimbulkan bau busuk. Wolin (1979) melaporkan bahwa bakteri tahan panas (thermophilic bacteria) masih dapat hidup hingga suhu lingkungannya mencapai $98^{\circ} \mathrm{C}$. Tingkat ketahanan bakteri tahan panas tidak hanya dipengaruhi oleh proses panas yang diberikan tetapi juga oleh komposisi bahan, misalnya kandungan lemak yang tinggi yang akan meningkatkan ketahanan terhadap panas beberapa jenis bakteri.

Kemungkinan faktor inilah yang menyebabkan kandungan lisin perlakuan A dan B cepat menurun. Di samping itu, perlakuan A dan B tidak dikemas dengan sempurna sehingga terjadi kontaminasi selama penyimpanan. Sebagai akibatnya lisin diuraikan oleh bakteri menjadi ornitin, putresin dan kadaverin. Sedangkan kerusakan lisin yang terjadi pada perlakuan sterilisasi (C dan D) selama penyimpanan mungkin didominasi oleh reaksi kimia seperti reaksi Maillard, dan reaksi ketengikan atau kombinasi keduanya seperti yang dinyatakan oleh Fennema (1976) bahwa reaksi antara kelompok karbonil dengan $\epsilon$-amino lisin akan membentuk lisinoalanin dan piperidin. 
Basmal, J.; Utomo, B.S.B.; dan Taylor, K.D.A.


A: perebusan dalam 10\% larutan garam selama 22 menit (boiled in 10\% brine solution for $22 \mathrm{~min}$ )

B: perebusan dalam larutan garam jenuh selama 36 menit (boiled in saturated brine for 36 min)

C: perebusan pendahuluan selama 10 menit dengan penambahan $10 \%(\mathrm{~b} / \mathrm{b})$ garam kristal kemudian pada suhu $121^{\circ} \mathrm{C}$ selama 72 menit an then sterilized)

D: perebusan pendahuluan selama 10 menit dengan penambahan $10 \%(\mathrm{~b} / \mathrm{b})$ garam kristal kemudian dikemas vakum dan disterilkan pada suhu $121^{\circ} \mathrm{C}$ selama 72 menit waktu proses ( pre-cooked with addition of $10 \%(w / w)$ crystal salt, vacuum
packed and then sterilised)

Gambar 3. Penurunan kandungan lisin ikan pindang selama penyimpanan.

Figure. 3. The decrease of available lysine on boiled salted fish during storage.

\section{KESIMPULAN DAN SARAN}

\section{Kesimpulan}

Selama pengolahan, kombinasi suhu tinggi dan penambahan garam ( $10 \%$ bobot kering), serta pengemasan tanpa vakum dapat mengurangi lisin hingga $53,17 \%$, tetapi apabila penggunaan suhu tinggi dan penambahan garam $(10 \%$ bobot kering) dikombinasikan dengan pengemasan vakum kerusakan lisin dapat dikurangi menjadi $7,63 \%$. Sedangkan penggunaan larutan garam jenuh untuk merebus ikan dalam proses peng. olahan ikan pindang telah menghilangkan kandungan lisin sebesar $41,56 \%$.

Selama penyimpanan, pengurangan kandungan lisin pada perlakuan A dan B sebagian besar disebabkan oleh aktivitas bakteri dan reaksi oksidasi, sedangkan pada perlakuan $\mathrm{C}$ dan $\mathrm{D}$ disebabkan karena reaksi asam amino lisin dengan gugus karbonil yang terbentuk akibat penggunaan suhu sterilisasi. Di samping akibat suhu, kerusakan yang terjadi pada perlakuan C juga dipengaruhi oleh oksigen karena produk tidak dikemas vakum. Tetapi kecepatan kerusakan lisin pada perlakuan $\mathrm{C}$ dan $\mathrm{D}$ ini relatif lebih lambat dibandingkan dengan perlakuan A dan B. Cara yang terbaik untuk mengurangi penurunan kandungan lisin ikan pindang baik selama peng. olahan maupun penyimpanan adalah dengan proses sterilisasi dan dikemas menggunakan bahan pengemas kedap udara.

\section{Saran}

Untuk menghindari terjadinya proses oksidasi lemak selama penyimpanan ikan pindang yang telah disterilisasikan dan dikemas secara vakum, sebaiknya bahan pengemas yang digunakan kedap udara dan berwarna gelap agar pengaruh cahaya dapat dihindari. 


\section{DAFTAR PUSTAKA}

Anonymous. 1972. Quality aspect in handling and storage of fish. FAO/DANIDA Training Course. Technical University Lyngby, Denmark. pp: 8 - 9.

Bramstedt, F. and M. Auerbach. 1961. The spoilage of fresh water fish. G. Borgstrom (Ed). Fish as Food. Academic Press, New York. 1:613-633.

Collins C.H.; P.M. Lyne and J.M. Grange. 1989. Microbial methods. 6th Edition. Butterworth \& Co (Publishers) Ltd, London.

Fennema, O.R. 1976. Principles of food science. part I. Food Chemistry. Marcel Dekker. Inc., New York.

Finley, J.W. 1985. Environmental effects on protein quality. T. Richardson (Ed) Chemical Changes in Food during Processing. AVI Publishing Co., Inc. Westport, Connecticut. 443-482.

Labuza, T.P. 1972. Kinetics of lipid oxidation in foods. Critical Rec. Food Technol. 2(3),355-405.
Peterson, W.R. and J.J. Warthesen. 1979. Total and available lysine determination using high pressure liquid chromatography. J. Food Sci. 44:994-997.

Tooley, P.J. and R.A. Lawrie. 1974. Effects of deep fat frying on the availablity of lysine in fish fillets. $J$. Food. Technol. 9:247-253.

Yen, G.C. and J.D. Lii. 1995. Influence of the reaction conditions on the antimutagenic effect of Maillard reaction products derived from xylose and lysine. $J$. Agric. Food. Chem. 40:1034-1037.

Stumbo, C.R. 1973. Thermobacteriology in food processing ( $2^{\text {nd }}$ ed) Academic Press., Inc. London.

Wheaton F.W. and T.B. Lawson. 1985. Processing aquatic food products. A Wiley-Interscience Publication. John Wiley \& Sons. New York.

Wolin, M.J. 1979. Physical agents, bactericidal substances (disinfectances), and chemotherapeutic drugs. B.A. Freeman (Ed). Textbook of Microbiology. $21^{\text {st }}$ edition. E.B. Sounders Comp. Philadelphia. $\mathrm{pp}: 122-156$ 
Basmal, J.; Utomo, B.S.B.; dan Taylor, K.D.A.

Lampiran 1. Teknik menghitung nilai $F_{o}$ pada perlakuan $C$ dan $D$ yang disterilkan menggunakan retort vertikal pada $121^{\circ} \mathrm{C}$ selama 72 menit waktu proses.

Appendix 1. Fo value computation of treatment $C$ and $D$ sterilized using vertical retort at $121^{\circ} \mathrm{C}$ for 72 minute processing time.

\begin{tabular}{|c|c|c|c|c|}
\hline $\begin{array}{l}\text { Waktu (menit) } \\
\text { Time (minute) } \\
\text { (A) }\end{array}$ & $\begin{array}{c}\text { Suhu retort } \\
\text { Retort temp. }\left({ }^{\circ} \mathrm{C}\right) \\
(B)\end{array}$ & $\begin{array}{l}\text { Suhu ikan rata-rata } \\
\text { Average fish temp. }\left({ }^{\circ} \mathrm{C}\right) \\
\text { (C) }\end{array}$ & $\begin{array}{l}\text { Nilai L } \\
\text { L-value } \\
\text { (D) }\end{array}$ & $\begin{array}{l}\text { Total } \\
\sum \text { L.dt } \\
(E)\end{array}$ \\
\hline 0 & 9.2 & 10.95 & & \\
\hline 10 & 119.5 & 101.55 & 0 & 0 \\
\hline 12 & 119 & 106.3 & 0.02 & 0.04 \\
\hline 14 & 122.2 & 114.95 & 0.09 & 0.18 \\
\hline 16 & 120.4 & 116.05 & 0.28 & 0.55 \\
\hline 18 & 121.55 & 118.3 & 0.4 & 0.81 \\
\hline 20 & 121.45 & 118.85 & 0.56 & 1.12 \\
\hline 22 & 121.6 & 119.25 & 0.62 & 1.25 \\
\hline 24 & 121.6 & 119.5 & 0.67 & 1.34 \\
\hline 26 & 121.7 & 119.65 & 0.7 & 1.41 \\
\hline 28 & 121.8 & 119.8 & 0.75 & 1.5 \\
\hline 30 & 115.8 & 115.35 & 0.44 & 0.89 \\
\hline 32 & 110.7 & 110.85 & 0.16 & 0.32 \\
\hline 34 & 106.9 & 107.95 & 0.07 & 0.14 \\
\hline 36 & 103.75 & 105.45 & 0.04 & 0.07 \\
\hline 38 & 101.2 & 103.3 & 0.02 & 0.04 \\
\hline 40 & 96.5 & 99.55 & 0.01 & 0.02 \\
\hline 42 & 96.45 & 95.55 & 0 & 0 \\
\hline 44 & 96.25 & 94 & 0 & 0 \\
\hline 64 & 79.35 & 73.25 & 0 & 0 \\
\hline 66 & 77.85 & 71.8 & 0 & 0 \\
\hline 68 & 76.25 & 69.95 & 0 & 0 \\
\hline 70 & 75.1 & 70.15 & 0 & 0 \\
\hline 72 & 73.4 & 58.7 & 0 & 0 \\
\hline \multicolumn{4}{|c|}{$\Sigma F_{0}$} & 9.66 \\
\hline
\end{tabular}

Ikan yang digunakan untuk mengukur suhu pada pusat badan ikan selama proses berlangsung adalah 4 ekor pada perlakuan $\mathrm{C}$ dan 4 ekor ikan untuk D (Total fish used to monitor internal body fish temperature were 4 fish for treatment $C$ and 4 fish for treatment D)

Nilai L (kolom D) ditetapkan menggunakan tabel Stumbo ( L-value (column D) was computed by using Stumbo's table) (1973) Total $\Sigma$ L.dt $($ kolom E) $=($ kolom C $x$ kolom D)/kolom A (Total $\Sigma$ L.dt $($ column E) $=($ column C $x$ column D)/column A $)$ 